\title{
Enrique García Catalán, Una ciudad histórica frente a los retos del urbanismo moderno. Salamanca en el siglo XIX., Ediciones Universidad Salamanca, Salamanca 2016, pp. 496, il.
}

The nineteenth century is the time of cities whose development is inherent in the definition of modernity, as described i.a. by Jürgen Ostelhammel, Maria Nietyksza, Krzysztof K. Pawłowski, Tomasz Kizwalter and Miron Urbaniak $^{1}$. This issue was also addressed at the 20th Universal Congress of Polish Historians, where an entire thematic section was devoted to it. Also in Spain researchers are currently conducting intensive research on urbanization processes, which is reflected in a number of publications devoted not only to the largest centres but also small towns, with Valladolid, Logroño, Toledo or Palencia already having their own monographs².

Published in 2016 Enrique García Catalán's Una ciudad histórica frente a los retos del urbanismo modern. Salamanca en el siglo XIX is part of this research scope. It was published as the 29th volume of the 'Biblioteca del Arte' series of the University of Salamanca. Located in Castile and inhabited by over 160,000 people, Salamanca is of great importance for the history of Spain. It is the home of the oldest functioning Spanish university. During the nineteenth century, the number of its inhabitants increased from 15,000 to 26,000 , so the dynamics of urbanization processes were rather poor. Comparing Salamanca with other urban centres in Spain, García Catalán

1 J. Osterhammel, Historia XIX wieku. Przeobrażenie świata, trans. J. Kałążny, Poznań 2013; M. Nietyksza, Urbanizacja - jej źródła i miejsce w rozwoju cywilizacji europejskiej w "długim” XIX wieku (do 1914 r.), in: Cywilizacja europejska. Eseje i szkice z dziejów cywilizacji i dyplomacji, ed. M. Koźmiński, Warszawa 2010; T. Kizwalter, Miasto i nowoczesność, in: Ziemia obiecana. Miasto i nowoczesność, Warszawa 2015. The work of M. Urbaniak supports the claim that urban modernisation should be studied not only in the context of large urban centres - see M. Urbaniak, Leszno w latach 1832-1914. W drodze ku nowoczesności, 2nd ed., Łódź 2016.

2 B. Calderón, Cartografía y ciudad. Valladolid en el siglo XIX. Transformaciones espaciales en el inicio del proceso urbano Contemporáneo, Valladolid 1991; R. Cerrillo, La formación de la ciudad contemporánea Logroño entre 1850-1936, Logroño 1993; R. Cerro Malagón, Arquitecturas y espacios para el ocio en Toledo durante del siglo XIX, Toledo 1989, P. Garcia Colmenares, La ciudad Palencia en siglo XIX. La desamortización y su transformación urbanística (1836-1868), Palencia 1986. 
emphasizes that the changes occurred faster in places where industry and trade were developing.

The publication reviewed is an abridged version of the author's $\mathrm{PhD}$ dissertation, prepared under the supervision of Maria Nieves Rupérez Almajano and defended in 2013 at the University of Salamanca. The silhouette of the supervisor is of extreme importance, as Rupérez Almajano is an art historian and author of a paper on the urban development of Salamanca in the 18th century. There are multiple references to her work throughout the book reviewed herein ${ }^{3}$. Even before obtaining the PhD degree, the author had published several papers on the history of Salamanca, focusing on its urban architecture or infrastructure. A year after publishing the book at issue he published another one, entitled Salamanca abandonada, sucia y obscura: Las infraestructuras del siglo $X I X^{4}$. The author may be therefore considered a specialist in the field of the nineteenth-century Salamanca, with his individual publications describing particular aspects related to the modernization of the city in the nineteenth century.

Translated as Historical city facing the challenges of modern urban planning: Salamanca in the nineteenth century, the title itself indicates the author's focus on only one determinant of the modern city, that is, the new urban layout developed throughout the nineteenth century and still visible today. The book consists of twelve chapters. In the first part the author outlines the social situation in the city, attitudes to urban reforms and legal regulations. He provides an in-depth analysis of the changes in the provisions regarding the city reconstruction as well as plans (e.g. prepared by such engineers as Francisco Coello or Francisco Garcia San Pedro), which laid the groundwork for urbanization projects. An important point of the author's considerations were also the institutions responsible for the urban development of the city. In the following chapters, García Catalán discusses the urban development of particular places, dividing the city into the inner part (within the walls) and the outer part. A separate chapter is devoted to the city walls only, whose destruction heralded the arrival of modern urban changes in almost every city. In the case of Salamanca, the decisions on demolishing the walls were made simultaneously with the subsequent stages of urban development of the city. Their last fragment

3 M.N. Rupérez Almajano, Urbanismo de Salamanca en el siglo XVIII, Salamanca 1992.

4 E. García Catalán, El monasterio de San Vincente de Salamanca, Salamanca 2005; El ferrocarril a Medina del Campo. Llegada de la "vertiginosa actividad moderna" a Salamanca ('Salamanca Revista de Estudios' 2016) czy Infraestructura Castrense de Salamanca en el siglo XIX. Cuarteles y Hospitales Militares ('Revista de Historia Militar' 2016); Salamanca abandonada, sucia y obscura: Las infraestructuras del siglo XIX, Salamanca 2017. 
was removed in 1902. The author devotes an interesting yet concise fragment of the book to the Salamancan street names. They are described in two chronological sections, the first of which concerns the changes after the First Karlist War, while the second one characterises the changes in the second half of the 19th century.

The author attempts to present how the city authorities dealt with the challenges imposed by the changes of the nineteenth century in the field of spatial planning. This age did not start happily for Salamanca - many urban buildings suffered as a result of the War of Independence, and its effects were the starting point for urban changes in the city. The author clearly emphasizes that this event and the Karlist wars slowed down the development of Salamanca and interrupted initiatives initiated in the 18th century. The author finishes his narrative in the first decade of the 20th century, during which occurred the last demolition of the city gate (1902) or changes in the city building regulations (1908).

In his work, the author analyses modern changes in the urban landscape, including the reconstruction and development of squares, planning new streets as well as widening, levelling and extending the existing ones, creation of public green spaces (gardens and parks, e.g. in the Plaza Mayor). This type of activity was most intensive in the second half of the 19th century. García Catalán also depicts the city's policy towards monuments.

For the author, the biggest problem which the Salamanca authorities have faced was the inevitable interventions in the historical centre of the city. They led to decisions that García Catalán describes as controversial and even fatal to the historical urban fabric. In this context, he describes the activity of the provincial Comision de Monumentos, operating since 1844, which failed to properly look after the churches, palaces and monuments of 'undisputed artistic and archaeological value' ${ }^{\prime}$. As a result, numerous historical buildings (listed in the annex) disappeared. García Catalán is critical of the activities which led to the demolition of Puerta del Rio in 1902. However, he argues that political events (such as the war of independence) or confiscations of church property carried out in the nineteenth century also greatly contributed to the devastation of the city. Focused on urban planning, the author did not include the chapters on street lighting or the city's water supply in the book. They were present in his $\mathrm{PhD}$ dissertation, and definitely comprise elements of a modern city. Hence the book's consistent and logical layout, especially since the other aspects of a modern city are presented in the other publications of García

5 E. García Catalán, Una ciudad histórica frente a los retos del urbanismo moderno. Salamanca en el siglo XIX., Salmanca 2016, p. 438. 
Catalán. It should be noted, however, that the author decided to include the chapters on communication routes and railways. In the context of the latter, he stresses that the 1877 inauguration of the railway line leading to Medina el Campo in the presence of King Alfonso XII himself was an act of 'welcoming the modernity'.

As mentioned above, the title of the book refers to urban changes in Salamanca in the nineteenth century, which is confirmed by the structure of the book. García Catalán focuses on urban changes inside and outside the walls, devoting specific subchapters to individual squares, streets or suburbs. He meticulously described such places as the representative Plaza Mayor, a showcase of the city, whose modern character was a result of the cobbled surface, new trees, and an iron pavilion for a music band which replaced the fountain. The author does not analyse urban changes in isolation from the historical context. On the contrary, he refers to important political events, such as the War of Independence, the Spanish confiscation, revolution of 1868, or Karlist wars, which all had an impact on the city.

The work is based on an extensive base of sources. The author used not only local resources found in the university archives and libraries or the diocesan, municipal and provincial archives, but also examined sources available at national centres such as Archivo Real Academia de la Historia, Archivo Historico Protocolos de Madrid, Real Academia de Bellas Artes de San Fernando (which houses albums with photos of Salamanca taken by Charles Clifford, a Brit), or Archivo Averly S.A. The last place may seem particularly interesting. Averly was originally a foundry established in 1863, which supplied machines for industry, agriculture, health and transport. It also produced urban furniture (e.g. benches). The publication complement scans of historical documents and contemporary photos of the monuments described.

Annexes are a very good addition to the book. The first annex compiles objects (along with their brief characteristics) that disappeared from the urban system as a result of the war for independence, confiscation or 'urban speculation'. These are mostly convents, monasteries and churches, but also city gates and three historic bridges. The second annex is devoted to nineteenth-century institutions such as hospitals, offices, barracks, educational and cultural centres. Similarly to the first annex, it has a form of a table with the name of the object and a concise description of its history in the nineteenth century. The tables at the end of the book list street names along with the names of the architects who had designed

\footnotetext{
$6 \quad$ Ibidem, p. 89.
} 
them. One table is in alphabetical order, while the other organizes items in chronological order. These appendices help systematise the knowledge presented on the pages of this publication.

The work of Enrique García Catalán was prepared with great diligence. The amount of information collected by the author as well as his research proficiency is truly remarkable. The reader may be slightly dissatisfied, however, with Salamanca being described in isolation from the general context of the development of Spanish cities in the nineteenth century. The case of Salamanca might not have been exceptional, but it would certainly be interesting to specify which features of modern urbanization distinguished it from other cities.

In his article entitled The birth of a modern city, Krzysztof K. Pawłowski coined a definition of a modern city which can be found in many research papers today: 'A modern city can be understood as an urban organism which was able to provide its inhabitants with optimal living and cultural development by making the most out of civilization achievements ${ }^{7}$ The work of Enrique García Catalán describes how Salamanca became a modern 'urban organism'. Without this transformation, no other modernisation processes could ensue in the city.

Agata Eysakowska-Trzoss

(Adam Mickiewicz University, Poznań) https://orcid.org/0000-0001-8065-5645

\section{REFERENCES}

Calderón B., Cartografía y ciudad. Valladolid en el siglo XIX. Transformaciones espaciales en el inicio del proceso urbano Contemporáneo, Valladolid 1991.

Cerrillo R., La formación de la ciudad contemporánea Logroño entre 1850-1936, Logroño 1993.

Cerro Malagón R., Arquitecturas y espacios para el ocio en Toledo durante del siglo XIX, Toledo 1989.

García Catalán E., El ferrocarril a Medina del Campo. Llegada de la "vertiginosa actividad moderna" a Salamanca, 'Salamanca Revista de Estudios' 2016.

García Catalán E., El monasterio de San Vincente de Salamanca, Salamanca 2005.

García Catalán E., Infraestructura Castrense de Salamanca en el siglo XIX. Cuarteles y Hospitales Militares, 'Revista de Historia Militar' 2016.

García Catalán E., Salamanca abandonada, sucia y obscura: Las infraestructuras del siglo XIX, Salamanca 2017.

García Catalán E., Una ciudad histórica frente a los retos del urbanismo moderno. Salamanca en el siglo XIX., Salamanca 2016.

7 K.K. Pawłowski, Narodziny miasta nowoczesnego, in: Sztuka 2. połowy XIX wieku, ed. T. Hrankowska, Warszawa 1973, p. 52. 
Garcia Colmenares P., La ciudad Palencia en siglo XIX. La desamortización y su transformación urbanística (1836-1868), Palencia 1986.

Kizwalter T., Miasto i nowoczesność, in: Ziemia obiecana. Miasto i nowoczesność, Warszawa 2015.

Nietyksza M., Urbanizacja - jej źródła i miejsce w rozwoju cywilizacji europejskiej w 'dtugim' XIX wieku (do 1914 r.), in: Cywilizacja europejska. Eseje i szkice z dziejów cywilizacji $i$ dyplomacji, ed. M. Koźmiński, Warszawa 2010.

Osterhammel J., Historia XIX wieku. Przeobrażenie świata, transl. J. Kałążny, Poznań 2013.

Pawłowski K.K., Narodziny miasta nowoczesnego, in: Sztuka 2. połowy XIX wieku, ed. T. Hrankowska, Warszawa 1973.

Rupérez Almajano M.N., Urbanismo de Salamanca en el siglo XVIII, Salamanca 1992.

Urbaniak M., Leszno w latach 1832-1914. W drodze ku nowoczesności, 2nd ed., Łódź 2016. 